\title{
HISTOLOGICAL CHANGES ON MILKFISH SKIN (Chanos chanos) DURING POSTMORTEM
}

\author{
Medal Lintas Perceka1), Tati Nurhayati1)*, Sri Nuryati2) \\ 1) Departement of Aquatic Product Technology, 2) Departement of Aquaculture, \\ Bogor Agricultural University \\ *)e-mail: nurhayati7870@yahoo.com
}

\begin{abstract}
Aquatic products are easily perishable commodity, one of them are fish skin. Information about the declining quality of milkfish skin has not been revealed yet. Milkfish skins were analysed to determine the chemical composition, postmortem storage on chilling temperatures, and compared the microstructure changes during postmortem. Measured parameters in this study were proximate, organoleptic score, and histological examination to observe the tissue damage that occurred in post mortem storage. Milkfish skin contained moisture, ash, lipid, protein, and carbohydrate were $64.74 \% ; 2.43 \% ; 4.76 \% ; 23.74 \% ; 4.34 \%$, respectively. Milkfish skin entered prerigor at 0 days, rigormortis at 8 days, postrigor at 14 days, and the decomposed phase at 23 days of chilled storage. Milkfish skin began experiencing damage in rigormortis by the occurrence of degeneration. In postrigor and decomposed phase occurred cariolysis. In addition, in the decomposed phase there were empty spaces marked by the loss of the milkfish skin tissue due to cell death.
\end{abstract}

Keyword: chilling, histology, milkfish skin, postmortem.

\section{INTRODUCTION}

Milkfish is one of the abundant fish species and potent commodities in Indonesia. Milkfish production highly increased 47,19\% in 2010 (Kelompok Kerja Data Statistik Kelautan dan Perikanan 2010). Fish skin is part of fish body that can be used as a raw material for manufacturing process such as fish crackers, gelatin, gelatin hydrolisate, edible/biodegradable film and collagen. Fish skin is rapidly degraded during postmortem storage as well as whole fish.

Microbial and chemical methods as well as sensory changes have been analysed to evaluated fish freshness (Olafsdottir et al. 1997; Nurjanah et al. 2004; Roth et al. 2006; Nurilmala et al. 2009; Ocano-Higuera et al. 2009; Ocano-Higuera et al. 2011 , Li et al. 2011 ). Information about the declining quality of milkfish skin has not been revealed yet, especially on histological changes during postmortem. Histological examinations are needed to uncover hidden quality of raw material.

The objectives of this study were to determine chemical composition of milkfish skin, postmortem storage on chilling temperature and to demonstrate microstructure of milkfish skin during postmortem.

\section{MATERIAL AND METHOD}

Milkfish with size 200-250 gram/body were purchased from the farmer's pond in Kampung Melayu, Teluk Naga, Tanjung Pasir, Tangerang-Banten regency, Indonesia. Milkfish 
were freshly caught and completely free of additives. All fish were killed immediately and stored at chilling temperature.

$\mathrm{H}_{2} \mathrm{SO}_{4}$, kjeltab selenium, $\mathrm{NaOH}, \mathrm{H}_{3} \mathrm{BO}_{3}$, n-hexana, $\mathrm{HCl}, 10 \%$ neutral buffered formaline, 50-100\% alcohol, xylol, hematoxylin, eosin, and mounting agent were purchased from MERCK (Darmstadt, Germany), parafin was purchased from Thermo Scientific (Cheshire, UK).

Moisture, ash, lipid and protein content of milk fish skin were determined by AOAC (1995), and carbohydrate was counted by difference method. Whole milkfish were observed by organoleptic tests to determined every phase on postmortem changes.

\section{Histological preparation}

Milkfish skin were observed by organoleptic test. It took from every phase on postmortem changes. The skin was cut from dorsal portion and prepared for histological examination. These samples were immersed in fixative solution, alcohol, xylol, embedded in parafin, blocking, staining with hematoxylin eosin, and cell adhesion using mounting agent (Angka et al. 1990).

\section{RESULT AND DISCUSSION}

\section{Proximate composition}

Proximate composition of the milkfish skin was determined (Fig. 1). Its moisture content was $64,74 \%$. Moisture content represent freshness and shelf life on foodstuff.

Ash content on fish skin probably derived from dermis layer. Angka et al. (1984) noted that teleostei fish scales is a dermis bone consisting of a mineral matrix of collagen fibers wrap thick. Ash content on milkfish skin was 2,43\%. Jamilah et al. (2011) showed that ash content on Red Tilapia (Oreochromis nilotica) skin was $0,51 \%$. The difference of ash content on fish skin is caused by habitat, enviromental, species of fish, sizes, ages etc. Muyonga et al. (2004) showed that different ages of Lates niloticus affecting ash content on its skin. Skin from adult fish contain more ash than young one, probably because of increasing calcification of scales with age.

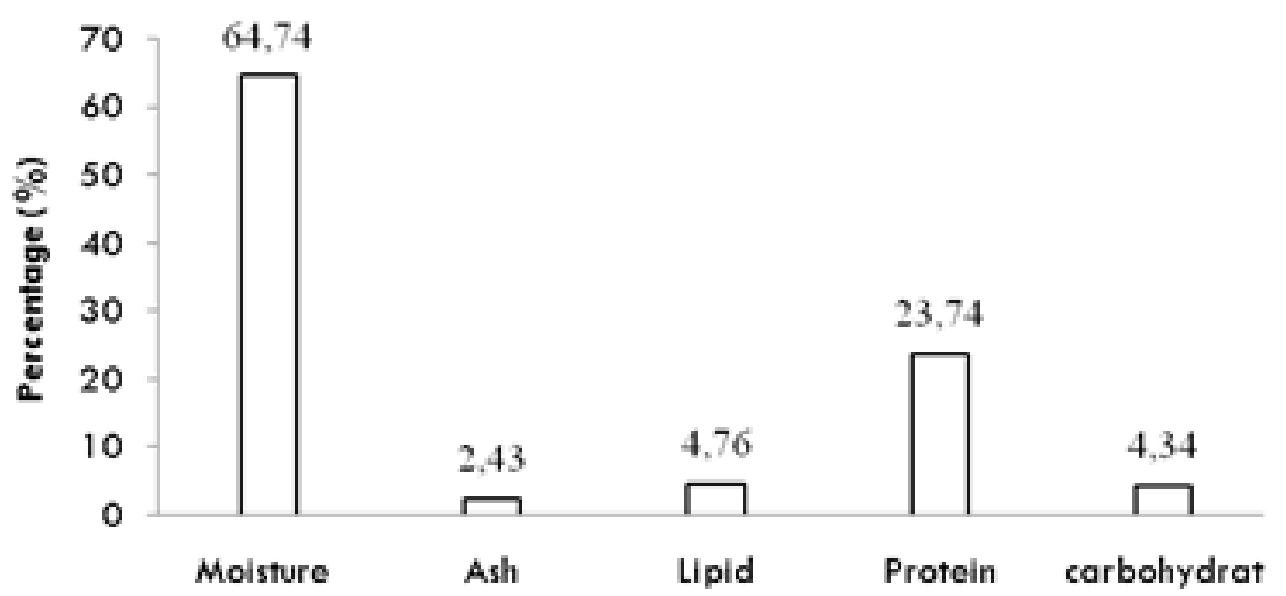

Figure. 1. Proximate composition of the fresh milkfish skin 
Lipid content on milkfish skin was $4,76 \%$. It contained high enough lipid. Lipid content on fish skin probably derived from hypodermis or subcutaneous layer. Chinabut et al. (1991) noted that hypodermis or subcutaneous is the deepest layer on fish skin. The most stricking characteristic of this layer is the presence of adipose cell. Different age of Lates niloticus show different lipid content on its skin (Muyonga et al. 2004). Skin from adult fish contain more lipid than young one, probably because the fish accumulate subcutaneous fat as their growth.

Protein content on milkfish skin was $23,74 \%$. The high protein content on fish skin may derived from dermis layer. Chinabut et al. (1991) noted that dermis layer on fish skin consisted of stratum spongiosum and stratum compactum, whereas both of these layer contained collagen. The main source of collagen on fish is in the skin and scales.

Carbohydrate content on fish skin has been counted by difference method. Carbohydrate content on fish skin was $4,34 \%$. This carbohydrate included polysaccharide calling glikogen. Hadim et al. (2002) noted that glikogen is a kind of carbohydrate which is abundant in fish. Angka et al. (1984) stated that glikogen is derived from excess glucose supply in blood. Stratum spongiosum on dermal layer consists of blood vessel distributing nutrients for skin.

\section{Organoleptic score}

Organoleptic score of milkfish skin (Chanos chanos) has been decreased during postmortem of chilled storage. Milkfish skin entered prerigor, rigormortis, postrigor and decomposed phase up to day $0,8,14,23$ of storage, respectively (Fig. 2).

Milkfish skin maintained high and good quality during the first 8 days and fair quality 913 days of chilled storage. Ozugul et al. (2006) showed that wild turbot skin (Scophtalmus maximus) aspect and consistency still be acceptable up to day 19 of chilled storage. Aubourg et al. (2005) and Rodriguez et al. (2006) studied farmed turbot and found high and good quality during the first 14 days of chilled storage and up to day 22 for turbot storage in slurry ice or up to day 14 for turbot in flake ice, respectively.

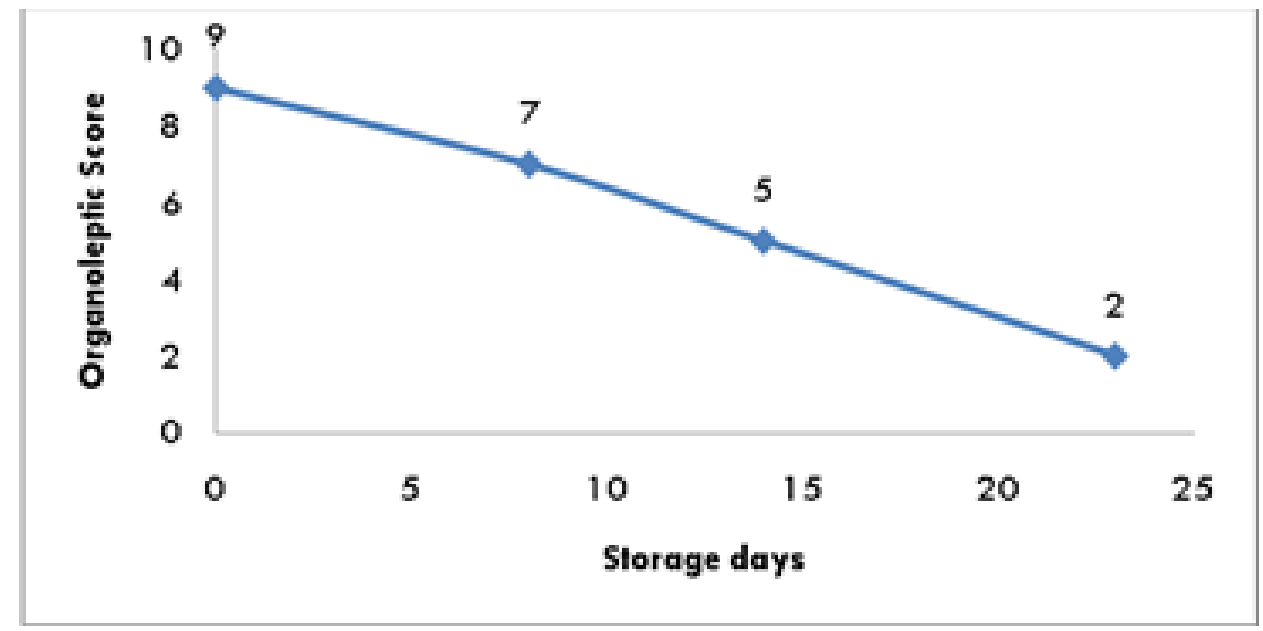

Figure. 2 Organoleptic score of the milk fish skin during postmortem of chilled storage. 


\section{Histological changes during postmortem}

Fish skin is highly composite structure that consist of squamous epidermis, the underlaying dermis and the last hypodermis or subcutaneous layer. Dermis layer can be differentiated in a stratum spongiosum and stratum compactum. Both strata characterized by their connective tissue, collagen bundles. Hypodermis or subcutaneous layer of fish skin characterized by their adipose cells and melanin (Chinabut et al. 1991).

Epidermis, dermis and hypodermis or subcutaneous layer on prerigor phase clearly appeared. The outer epidermis is dominated by mucocytes and melanin pigment. The dermis of Chanos chanos skin is differentiated into stratum spongiosum and stratum compactum. Both strata are characterized by their collagen bundles. The dermis of Chanos chanos is provided with a collagenous stratum compactum of considerable thickness, a stratum spongiosum with loosely arranged fibers. Collagen bundless in stratum spongiosum arranged in sponge patterns. As shown by histological methods, hypodermis or subcutaneous layer it was look like empty spaces. Cormack et al. (1994) stated that lipid in subcutaneous layer are lost when histological processing.

Fish skin is rapidly degraded during postmortem storage. Microstructure of fish skin has been changed during postortem storage (Figure. 3).
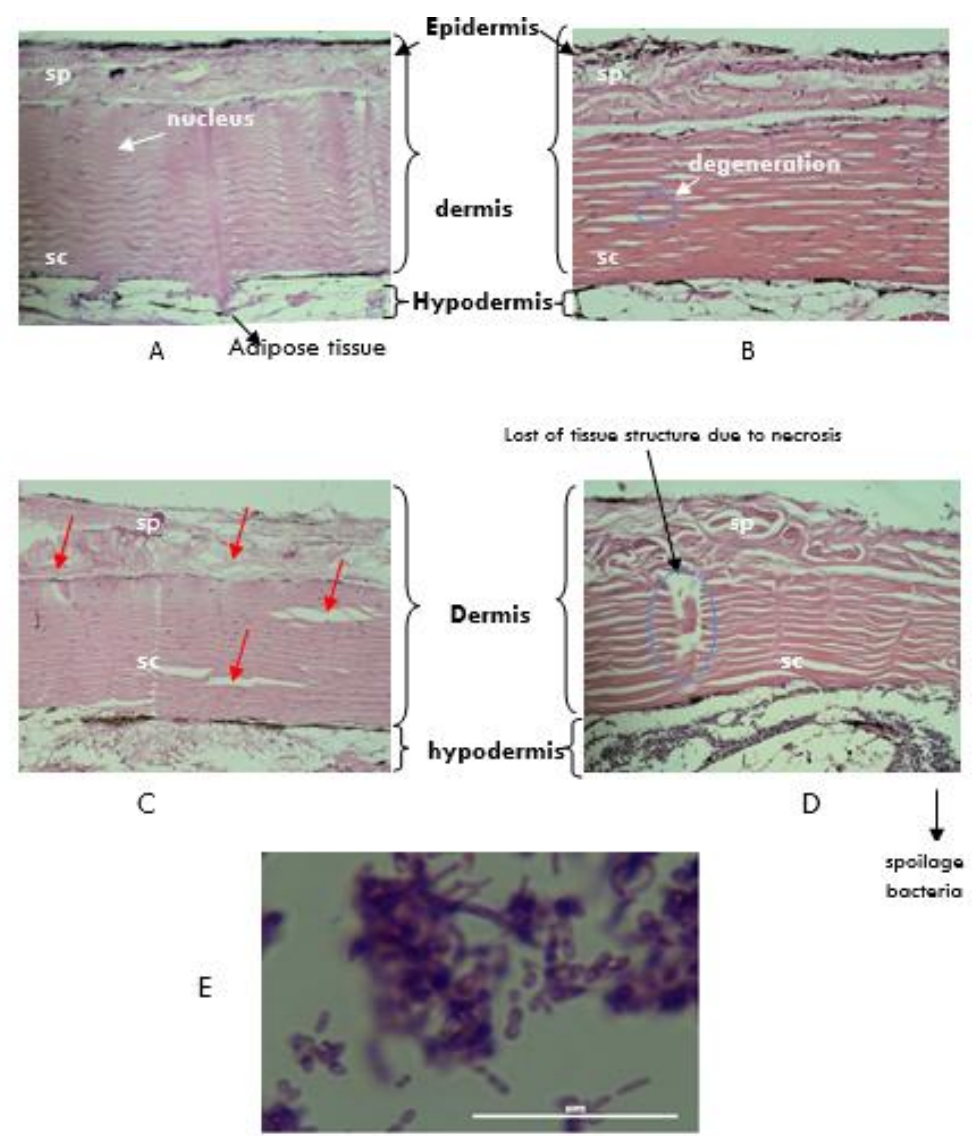

Figure. 3 Cross section milkfish of the dorsal skin stained with hematoxylin eosin; A prerigor phase, B rigormortis phase, C postrigor phase, D decomposed phase, E spoilage bacteria (sp: stratum spongiosum; sc: stratum compactum;

$\longrightarrow$ breakdown of collagen fibers) 
Milkfish skin began experiencing damage in rigormortis by the occurrence of degeneration. Degeneration is biochemical or structural changes or combination of them. Degeneration is an early step of necrosis (cell death). It was an irreversible and caused by lack of oxygen supply. It is disturbed cell metabolism. Degeneration of milkfish skin are characterized by swelling and thickening of collagen tissue.

In postrigor and decomposed phase are occurred cariolysis and breakdown of collagen fibers on dermal layer. Breakdown of collagen fibers may be caused by metalocollagenase enzyme. Cariolysis is the disintegration of a cell nucleus, which occurs on death cell. Cariolysis was characterized by lost of the cell nuclei in the tissue. In addition, the decomposed phases were empty spaces marked by the loss of the milkfish skin tissue due to cell death (necrosis). Spoilage bacteria was detected on decomposed phase.

\section{CONCLUSION}

Protein content on mikfish skin highly enough. Lipid and ash content on it was lower than protein. The organoleptic score of milkfish skin has been decreased during storage. Milkfish skin maintained high and good quality during the first 8 days of chilled storage. Microstructure of fish skin began damage in rigormortis phase.

\section{REFERENCES}

Angka SL, Mokoginta I, Dana D. 1984. Pengendalian Penyakit Ikan Histologi dan Hematologi Ikan-ikan Air Tawar yang Dibudidayakan. Departemen Pendidikan dan Kebudayaan. Direktorat Jenderal Pendidikan Tinggi. Institut Pertanian Bogor.

Angka SL, Mokoginta I, Hamid H. 1990. Anatomi dan Histologi Banding Beberapa Ikan Air Tawar yang Dibudidayakan di Indonesia. Departemen Pendidikan dan Kebudayaan. Direktorat Jendral Pendidikan Tinggi. Institut Pertanian Bogor.

AOAC.1995. Official methods of analysis (16th ed). Washington, DC: Association of Official Analytical Chemists.

Auborg SP, Pineiro C, Gallardo JM and Barros-velazquez J. 2005. Biochemical changes and quality loss during chilled storage of farmed turbot (Psetta maxima). Food Chem 90 : 445-452.

Chinabut S, Limsuwan C, Kitsawat P. 1991. Histology of The Walking Catfish, Clarias Bathracus. Departement of Fisheries Thailand.

Cormack DH. 1994. Buku Teks HAM Histologi. Tambajong J, penerjemah. Jakarta: Binarupa Aksara. Terjemahan dari: Ham's Histology.

Hadim E, Diawad MI and Karim MY. 2002. Kondisi glikogen dalam hati juvenil ikan bandeng (Chanos chanos Forskal) yang dibantut. J Teknol Pangan (3)3 : 1-9

Jamilah, Tan, Umi Hartina and Azizah. 2011 . Gelatins from three cultured freshwater fish skin obtained by liming process. Food Hydrocolloids 25(5) : 1256-1260.

Kelompok Kerja Data Statistik Kelautan dan Perikanan. 2010. Kelautan dan Perikanan dalam Angka. Jakarta: Kementerian Kelautan dan Perikanan.

Muyonga, Cole and Duodu. 2004. Extraction and physico-chemical characterisation of nile perch (Lates niloticus) skin and bone gelatin. Food Hydrocolloids 18(4) : 581-592.

Li X, Li J, Zhu J, Wang Y, Fu L and Xuan W. 2011. Postmortem changes in yellow grouper (Epinephelus awoara) fillet storage under vacuum packaging at $0{ }^{\circ} \mathrm{C}$. Food $\mathrm{Chem}$ $126(3): 896-901$.

Nurilmala M, Nurjanah and Utama RH. 2009. Kemunduran mutu ikan lele dumbo (Clarias gariepinus) pada penyimpanan suhu chilling dengan perlakuan cara mati. J PHPI 12(1) : 1-16. 
Nurjanah, Setyaningsih I, Sukarno and Muldani M. 2004. Kemunduran mutu ikan nila merah (Oreochromis sp.) selama penyimpanan pada suhu ruang. J PHPI 7(1) : 37-43.

Ocano-Higuera VM, Marquez-Rios E, Canizales-Davila M, Castillo-Yanez, Pacheco-AguilarR, Lugo-Sanchez ME, Garcia-Orozco and Graciano-Verdugo. 2009. Postmortem changes in cazon fish muscle stored on ice. Food Chem $116(4)$ : 933-938

Ocano-Higuera VM, Maeda-Martinez AM, Marquez-Rios E, Canizales-Rodríguez DF, CastilloYanez FJ, Ruíz-Bustos E, Graciano-Verdugo AZ and Plascencia-Jatomea M. 2011. Freshness assessment of ray fish stored in ice by biochemical, chemical and physical methods. Food Chem 125(1): 49-54.

Olafsdottir, Martinsdottir, Oehlenschbger, Dalgaard, Jensen, Undeland, Mackie, Henehan, Nielsen and Nilsen. 1997. Method to evaluate fish freshness in research and industry. Trends in Food Sci \& Technol 8(8) : 258-265.

Ozogul Y, Ozogul F, Kuley E, Ozkutuk, Gokbulut C and Kose S. 2006. Biochemical, sensory and microbiological attributes of wild turbot (Schophthalmus maximus) from the black sea during chilled storage. Food Chem 99(4): 752-758.

Rodriguez O, Barros-velazquez J, Pineiro C, Gallardo JM and Auborg SP. 2006. Effect of storage on slurry ice on the microbial, chemical and sensory quality and on the shelf life of farm turbot (Psetta maxima). Food Chem 95(2) : 270-278.

Roth B, Slinde E and Arildsen J. 2006. Pre or postmortem muscle activity in Atlantic salmon (Salmo salar); the effect on rigormortis and the physical properties of flesh. Aqualculture 257(1-4) : 504-510. 